With the rapid growth of knowledge about the structure of matter, many new techniques of physical, chemical or atomic origin have recently been introduced, and some of these are now developing into powerful analytical tools so that it is difficult for laboratory suppliers to predict the future requirements of chemists. Nevertheless, "Catalogue 56S", while giving proper place to the standard and classical apparatus, includes many items of newly designed apparatus for use in those recently introduced methods which are likely to be of permanent value in the modern laboratory. The firmly established 'Microid' and 'Nivoc' ranges of instruments are fully illustrated and described, frequently with very usoful experimental notes. Interesting examples of modern apparatus are the Griffin gas chromatographic apparatus, skeletal atomic models and a 6 -in. analytical fractionating column. The catalogue is excellently produced and extremely easy to use, and it should prove a valuable and comprehensive book of reference to modern laboratory apparatus for all scientists, not only chemists, in industry or engaged in teaching in technical colleges and the universities. Although many of the items are too elaborate or expensive for school use, school apparatus is not neglected, and it is recommended that school teachers and authors of school text-books make full use of "Catalogue 56 $S$ " for illustrating their lessons.

\section{East African Industrial Research Organization}

THE annual report for 1955-56 of the East African Industrial Research Organization (East Africa High Commission. Pp. ii +7 . Nairobi : Government Printer, 1956. Sh. 2), which includes a list of technical pamphlets issued by the Organization and its predecessors, records that the Organization is still in a transitional stage. The new laboratories and offices in Nairobi should be completed early this year and the metallurgical laboratory in Entebbe was expected to be ready before the end of 1956. Considerable progress was made in the coffee-drying project, particularly in the final stages of artificial drying. Further work was done on a refractory cement from local materials and a systematic study has been made of bodies using the buff or near white burning swamp clays found in Kenya for producing a domestic pottery bowl by a once-fired technique. By bleaching with activated earth, a cedarwood oil has been obtained equal in colour to the steam-distilled product and with only small losses.

\section{The National Research Council of Canada}

THE "National Research Council Review", 1956 (pp. 284+16 plates. Ottawa: Queen's Printer. 75 cents), describes the work of the National Research Council of Canada during 1955, but includes some later work. It supplements the information already given in the annual report for the year ended March 31, 1956 (see Nature, 179, 297; 1957). Besides the reports of the directors of divisions and heads of sections and of the work of the Council's many committees, it includes a directory of the Council's staff, numbering 2,125 on April 1, 1956, of whom 558 were scientific and 753 technical. The Review is distributed to scientists, research institutions and others who require more specialized information than is provided in the annual report.

\section{Special Schools for Handicapped Pupils}

THE Ministry of Education has produced a new edition of its booklet describing special schools for handicapped pupils (List of Special Schools for Handicapped Pupils in England and Wales. Pp. 72. (London: H.M. Stationery Office, 1956.) 3s. $6 d$. net). The schools are arranged according to the nature of the handicap for which they provide, and include those for the blind, partially sighted, deaf and partially deaf, educationally sub-normal, epileptics, maladjusted pupils, delicate and physically handicapped children, pupils suffering from speech defect, and hospital special schools. In each case the list includes details of the organization responsible for the school and the age-range of pupils and indicates whether or not pupils may be drawn from any part of the country. The list should be invaluable to local education authorities, head teachers and many distressed parents of handicapped children.

\section{Museum of Applied Arts and Sciences, Sydney}

ThE annual report for 1955 of this well-known Museum includes a record of many and varied activities. Although the Trustees sought a special grant of $£ 16,000$ to mark the seventy-fifth anniversary of the Museum by the purchase of a new Spitz Planetarium and an orrery, only $£ 3,000$ was forthcoming. Every effort was made by the Trustees to provide a new museum on another site in Sydney and thus enable them to carry out successfully their statutory obligations. An important addition to the electronics section was the installation of Foote's induction phones. This instrument, which resembles a stethoscope when placed in the ears, enables one to listen to the radio unencumbered by trailing wires. It operates by magnetic induction, and the public are invited to listen-in with these instruments. The most important installation was that of an electronic 'brain' which was constructed to allow visitors to participate by operating as a game of 'noughts and crosses'. The national character of the research work carried out by the staff is reflected in the published results, and in requests for information by overseas and local scientific colleagues, as well as by Australian industrial organizations. An example may be quoted in the advice and assistance furnished to an Australian firm which was attempting to establish a local peppermint and spearmint oil industry. The work of the scientific staff consisted mainly in investigations concerning the essential oils of Australian plants and their physiological forms. It is also reported that Mr. A. R. Penfold retired from the directorship on December 31,1955 , after thirty-seven years service. The Trustees pay a special tribute to him for the excellent results achieved during his administration by his initiative, enterprise and enthusiasm.

\section{Manchester City Library}

THe one hundred and fourth annual report of the Libraries Committee of the City of Manchester for the year ended March 31, 1956, points out that in the Reference Libraries, where the number of books issued increased by 114,842 , the main development has been in meeting the growing demand on the Technical Library, for which more spacious accommodation for users is required. There is also a growing demand for information calling for qualified staff, who must be sought in competition with industry, commerce and the teaching profession. Considerable progress was made during the year in redeploying staff to ensure the use of varying grades to the best advantage. The City Librarian's report records a book stock of $1,114,762$ volumes in the 